http://jmscr.igmpublication.org/home/ ISSN (e)-2347-176x ISSN (p) 2455-0450

crossref DOI: https://dx.doi.org/10.18535/jmscr/v8i11.91

\title{
Estimation of Serial Serum Albumin Level as a Prognostic Marker in Sepsis Patients Admitted in Intensive Care Units
}

\author{
Authors \\ Dr Saravanakumar.G ${ }^{1}$, Prof. Dr S. Balasubramaniyan.M.D²., Dr N.Paari M.D. ${ }^{3}$ \\ ${ }^{1}$ Post Graduate, Department of General Medicine, Rajah Muthiah Medical College \& Hospital, \\ Annamalai University, Chidambaram, India - 608002 \\ ${ }^{2}$ Professor, Department of General Medicine, Rajah Muthiah Medical College \& Hospital, \\ Annamalai University, Chidambaram, India - 608002 \\ ${ }^{3}$ Assistant Professor, Department of General Medicine, Rajah Muthiah Medical College \& Hospital, \\ Annamalai University, Chidambaram, India - 608002
}

\begin{abstract}
Introduction: Sepsis has very high morbidity and mortality, which leads to a major healthcare burden in the world. Though there is vast advancement in the therapeutic options, the mortality rate remains high due to the delay in the diagnosis because of the lack of availability of reliable diagnostic methods. In sepsis, there is potent activation of inflammatory cascade leading to endothelial dysfunction and an increase in systemic capillary permeability. In kidney, there is a loss of barrier integrity and capillary leak in the glomerulus resulting in increased excretion of albumin in the urine. The main objective of the study is to determine the role of serial monitoring of serum albumin levels as a predictor of mortality and morbidity in sepsis patients admitted in ICU and to find out whether there is a quantitative correlation between serum albumin levels and mortality risk associated.

Methodology: This descriptive study was conducted on 70 sepsis patients admitted in the medical intensive care unit and surgical intensive care unit in Rajah Muthiah Medical College \& Hospital, Annamalainagar, during the study period of November 2018 to August 2020. All the selected patients were completely evaluated and their serum albumin was measured on day 1 of sepsis diagnosis followed by day 3 and day 5. Patients were followed up during the course of hospital stay and the outcome of the patient (i.e. Death/Survival) was recorded. Data was entered in MS Excel sheet and analysed using SPSS (statistical product and service solutions) software version 18. Institutional Ethical Committee approval was obtained before the start of the study.

Results:The 70 patients selected for the study were divided into Survivor and non-survivor groups. The mean level of serum albumin at day 1 was $3.72 \mathrm{~g} / \mathrm{dl}( \pm 0.278)$ in survivor group and in non-survivors group, it was $3.11 \mathrm{~g} / \mathrm{dl}$ $( \pm 0.247)$. The mean level of serum albumin at day 3 was $3.17 \mathrm{~g} / \mathrm{dl}( \pm 0.248)$ in survivor group and in nonsurvivors group, it was $2.65 \mathrm{~g} / \mathrm{dl}( \pm 0.172)$. The mean level of serum albumin at day 5 was $2.72 \mathrm{~g} / \mathrm{dl}( \pm 0.25)$ in survivor group and in non-survivors group, it was $2.32 \mathrm{~g} / \mathrm{dl}( \pm 0.144)$. The difference in mean serum albumin in dayl, 3 and 5 was statistically significant with $p$ value $\leq 0.001$ by unpaired $t$ test. The decline in mean serum albumin level in survivors from day 1 to day 5 was $3.72 \mathrm{~g} / \mathrm{dl}$ to $2.72 \mathrm{~g} / \mathrm{dl}$. In non-survivors it is $3.11 \mathrm{~g} / \mathrm{dl}$ to $2.32 \mathrm{~g} / \mathrm{dl}$. Conclusion: In this study a serum albumin level below $3.5 \mathrm{gm} / \mathrm{dl}$ in all three days correlates directly with poor prognosis in sepsis patient. Both survivor and non-survivor groups had gradual fall in serum albumin level from day 1 , but the fall below $3.0 \mathrm{gm} / \mathrm{dl}$ was associated with higher mortality. It suggests that the rapidity with which serum albumin falls below the normal level has an effect on the prognosis of the sepsis patient in terms of mortality. Serum albumin measurement is cheaper and it's serial measurement may help in the clinical assessment of sepsis patient's, who is at the risk of poor prognosis even in resource poor areas.

Keywords: Serum albumin, Sepsis, Intensive care unit.
\end{abstract}




\section{Introduction}

Sepsis is a serious organ dysfunction caused by a dysregulated host response to infection. If not treated on time, it can lead to septic shock, multiple organ failure \& death. Sepsis has a high morbidity \& mortality, which leads to foremost healthcare problem in the world ${ }^{(1)}$. Though, there is progression in the therapeutic choices, the mortality rate remains high owing to the limited availability of trustworthy diagnostic methods and delay in the diagnosis. In sepsis, strong activation of inflammatory cascade leading to endothelial dysfunction and increase in systemic capillary permeability. In kidney, loss of barrier integrity and capillary leak in the glomerulus results in augmented elimination of albumin in the urine $\mathrm{e}^{(2)}$.

Albumin is the most abundant plasma protein, with normal serum levels between^3.5-5 g/dl. Synthesized in the liver, ^albumin is the prime factor in the maintenance of colloid osmotic pressure $^{(3)}$. A study done by yin-m et al found that albumin level of $<2.92 \mathrm{gm} / \mathrm{dl}$ at the time of admission was linked with increased 28 day mortality in patients with severe sepsis in a prospective cohort study ${ }^{(4)}$. Patients with serum albumin levels $<2.92$ $\mathrm{g} / \mathrm{dl}$ had a $46.7 \%$ mortality rate $\mathrm{vs}^{\wedge} 14.1 \%$ for those with levels above the cut-off.

A study done by Ranzani et al found that the $\mathrm{CRP} / \wedge$ albumin ratio measured on admission and discharge was projecting the 90-day mortality in patients with severe sepsis or septic shock ${ }^{(5)}$. Elevated CRP/ albumin ratios were obviously a outcome of high CRP, low serum albumin, or both and it is reasonable to doubt that serum albumin alone could have been a noteworthy predictor.

This highlights the significance of measurements of serial albumin levels. A low serum albumin concentration in critical illness is related with a poor outcome ${ }^{(6)}$. Serum albumin seems to be a trustworthy prognostic indicator in numerous circumstances $^{(7)}$. Albumin concentrations may be a marker for subclinical disease in elderly patients and most of the critically ill patients. In hospitalized patients, hypoalbuminemia is related with increased length of stay, higher complication rates and higher mortality ${ }^{(8,9)}$. Serum albumin level measurement is simple, less time consuming and easily available.

The main objective of this study is to determine the role of serial monitoring of serum albumin levels as predictor of mortality and morbidity in sepsis patients admitted in ICU and to find out whether there is quantitative correlation between serum albumin levels and mortality risk associated.

\section{Methodology}

This descriptive study was conducted on 70 sepsis patients admitted in medical intensive care unit and surgical intensive care unit in Rajah Muthiah Medical College \& Hospital, Annamalainagar, Tamilnadu, during the study period of November 2018 to August 2020.

\section{Inclusion Criteria}

- Adult aged over 18 years

- Patients who have a proven sepsis by culture.

- High suspicion of sepsis with following two or more variables

A. Temperature of more than $38^{\circ} \mathrm{c}$ $\left(100.4^{\circ} \mathrm{F}\right)$ or less than $36^{\circ} \mathrm{c}\left(96.8^{\circ} \mathrm{F}\right)$

B. Heart rate of more than 90 beats per minute

C. Respiratory rate of more than 20 breaths per minute or arterial carbon dioxide tension (paco2) of less than $32 \mathrm{~mm} \mathrm{Hg}$.

D. Abnormal white blood cell count $(>12,000 / \mu \mathrm{L}$ or $<4,000 / \mu \mathrm{L})$

\section{Exclusion Criteria}

- Chronic liver disease

- Chronic kidney disease with proteinuria

- Malnutrition

- Protein losing enteropathy.

- Patients who died within 5 days of admission. Informed written consent was obtained from each participant. All the selected patients were completely evaluated and their serum albumin was measured at the time of diagnosis of sepsis and day 3 and day 5 of diagnosis and correlated with clinical outcome (survivor/non-survivor) by phone after $28^{\text {th }}$ day of diagnosis. About $2 \mathrm{ml}$ of blood was drawn by venepuncture on day 1 of sepsis diagnosis followed by day 3 and day 5. Disposa- 
ble syringe and disinfectant was used. The study included patients with all etiologies with features of sepsis who were intubated and were put on mechanical ventilation. The decision for mechanical ventilation was taken by the treating physician.

A careful and detailed history was recorded and thorough clinical examination was conducted. Total blood counts, serum electrolytes, renal functions, liver functions and serum albumin (SA) done at the time of admission were also recorded. Blood culture and sensitivity and arterial blood gas analysis were obtained. Days on ventilator, days of ICU stay and days of hospital stay were recorded for all the patients. Data was entered in MS excel and analysed using SPSS software version 18. All quantitative variables are represented in mean, median, mode and standard deviation. Categorical variables represented in frequencies and percentages. Analysis of qualitative data was done using chi-square tests and quantitative data was done using unpaired t-test if data passes 'normality test' or else by Mann-Whitney Test. Pvalues less than 0.05 were considered statistically significant.

\section{Results}

In this study 70 sepsis patients admitted in medical intensive care unit and surgical intensive care unit were selected. Of the admitted 70 patients included in this study, 43 (61.42\%) patients were discharged from the hospital (survivors) and 27 $(38.57 \%)$ died in the hospital (non survivors).These patients were divided into Survivor and non-survivor groups. Mean (SD) age in the survivor group was 37.53 (10.48) and in the nonsurvivor group was 38.85 (10.53). The minimum and maximum age in the survivor group were 21 $\& 60$ respectively, in the non-survivor group it's was $21 \& 61$. In the survivor group $69.8 \%(n=30)$ were male and $30.2 \%(n=13)$ were females. In non-survivor group $77.8 \%(\mathrm{n}=21)$ were male and $22.2 \%(n=6)$ were female.

According to etiological diagnosis, in the survivor group $16.3 \%$ of patients had a stroke, $11.6 \%$ were snake bites, $9.3 \%$ were OP poisoning, and $9.3 \%$ patients were COPD. In the non-survivor group $25.9 \%$ of patients were stroke, $14.8 \%$ were OP poisoning, $14.8 \%$ were COPD and $11.1 \%$ were diabetic foot. According to causative organisms, $48.57 \%$ of the patients have had pseudomonas, $28.58 \%$ had E.Coli, $10 \%$ had MRSA, $8.58 \%$ had streptococci, $3.85 \%$ had klebsiella, and $1 \%$ of patients had anaerobes.

In our study, in the survivor group, $72.10 \%$ patients have normal serum albumin level in day 1 (g/dl) as compared to only $3.7 \%$ in non-survivor group. Mean level of serum albumin at day 1 was $3.72 \mathrm{~g} / \mathrm{dl}( \pm 0.278)$ in survivor group and in nonsurvivors group, it was $3.11 \mathrm{~g} / \mathrm{dl}( \pm 0.247)$. The difference in mean serum albumin in day 1 was statistically significant with t value 9.28, df 68 and $\mathrm{p}$ value $\leq 0.001$ by unpaired t test.

In the survivor group, $88.40 \%$ of patients have < $3.5(\mathrm{~g} / \mathrm{dl})$ serum albumin level on day 3 as compared to $100 \%$ in the non-survivor group. Normal serum albumin level $(\geq 3.5 \mathrm{~g} / \mathrm{dl})$ was $11.6 \%$ of patients have in the survivor group and $0 \%$ in nonsurvivors group. Mean level of serum albumin at day 3 was $3.17 \mathrm{~g} / \mathrm{dl}( \pm 0.248)$ in survivor group and in non-survivors group, it was $2.65 \mathrm{~g} / \mathrm{dl}(\underline{ \pm}$ 0.172 ). The difference in mean serum albumin in day 3 was statistically significant with $t$ value 9.496 , df 68 and $p$ value $\leq 0.001$ by unpaired $t$ test. In this present study, in the survivor group, 95.30 $\%$ of patients had $<3.5(\mathrm{~g} / \mathrm{dl})$ serum albumin level on day 5 as compared to $100 \%$ in the nonsurvivor group. Normal serum albumin level $(\geq 3.5$ $\mathrm{g} / \mathrm{dl}$ ) was found in $4.70 \%$ of patients in the survivor group and $0 \%$ in non-survivors group. Mean level of serum albumin at day 5 was $2.72 \mathrm{~g} / \mathrm{dl}( \pm$ $0.25)$ in survivor group and in non-survivors group, it was $2.32 \mathrm{~g} / \mathrm{dl}( \pm 0.144)$. The difference in mean serum albumin in day 5 was statistically significant with $t$ value 7.43 , df 68 and $p$ value $\leq 0.001$ by unpaired $t$ test. In our study the decline in mean serum albumin level in survivors from day 1 to day 5 was $3.72 \mathrm{~g} / \mathrm{dl}$ to $2.72 \mathrm{~g} / \mathrm{dl}$. In nonsurvivors it is $3.11 \mathrm{~g} / \mathrm{dl}$ to $2.32 \mathrm{~g} / \mathrm{dl}$. 


\section{JMSCR Vol||08||Issue||11||Page 526-531||November}

Table 1: Serum albumin levels in Survivor and non-survivor groups

\begin{tabular}{|l|c|c|c|}
\hline S.albumin in g/dl & Survivors(n=43) & Non-survivors $(\mathbf{n}=\mathbf{2 7})$ & Total $(\mathbf{n}=\mathbf{7 0})$ \\
\hline Day 1 & $12(27.9 \%)$ & $26(96.3 \%)$ & $38(54.28 \%)$ \\
\hline$<3.5$ & $31(72.1 \%)$ & $1(3.7 \%)$ & $32(45.71 \%)$ \\
\hline$\geq \mathbf{3 . 5}$ & $38(88.4 \%)$ & $27(100 \%)$ & $65(92.85 \%)$ \\
\hline Day 3 & $5(11.6 \%)$ & $0(0 \%)$ & $5(7.14 \%)$ \\
\hline$<3.5$ & $41(95.3 \%)$ & $27(100 \%)$ & $68(97.14 \%)$ \\
\hline$\geq 3.5$ & $2(4.7 \%)$ & $0(0 \%)$ & $2(2.85 \%)$ \\
\hline Day 5
\end{tabular}

Table 2 Comparing mean (SD) serum albumin in $\mathrm{g} / \mathrm{dl}$

\begin{tabular}{|l|c|c|c|c|c|}
\hline \multirow{2}{*}{ S.albumin in g/dl } & \multicolumn{2}{|c|}{ Mean (SD) } & \multirow{2}{*}{ t-value } & df & p-value \\
\cline { 2 - 6 } & Survivors & Non-survivors & & & \\
\hline Day 1 & $3.72( \pm 0.278)$ & $3.11( \pm 0.247)$ & 9.28 & 68 & $\leq 0.001$ \\
\hline Day 3 & $3.17( \pm 0.248)$ & $2.65( \pm 0.172)$ & 9.49 & 68 & $\leq 0.001$ \\
\hline Day 5 & $2.72( \pm 0.250)$ & $2.32( \pm 0.144)$ & 7.43 & 68 & $\leq 0.001$ \\
\hline
\end{tabular}

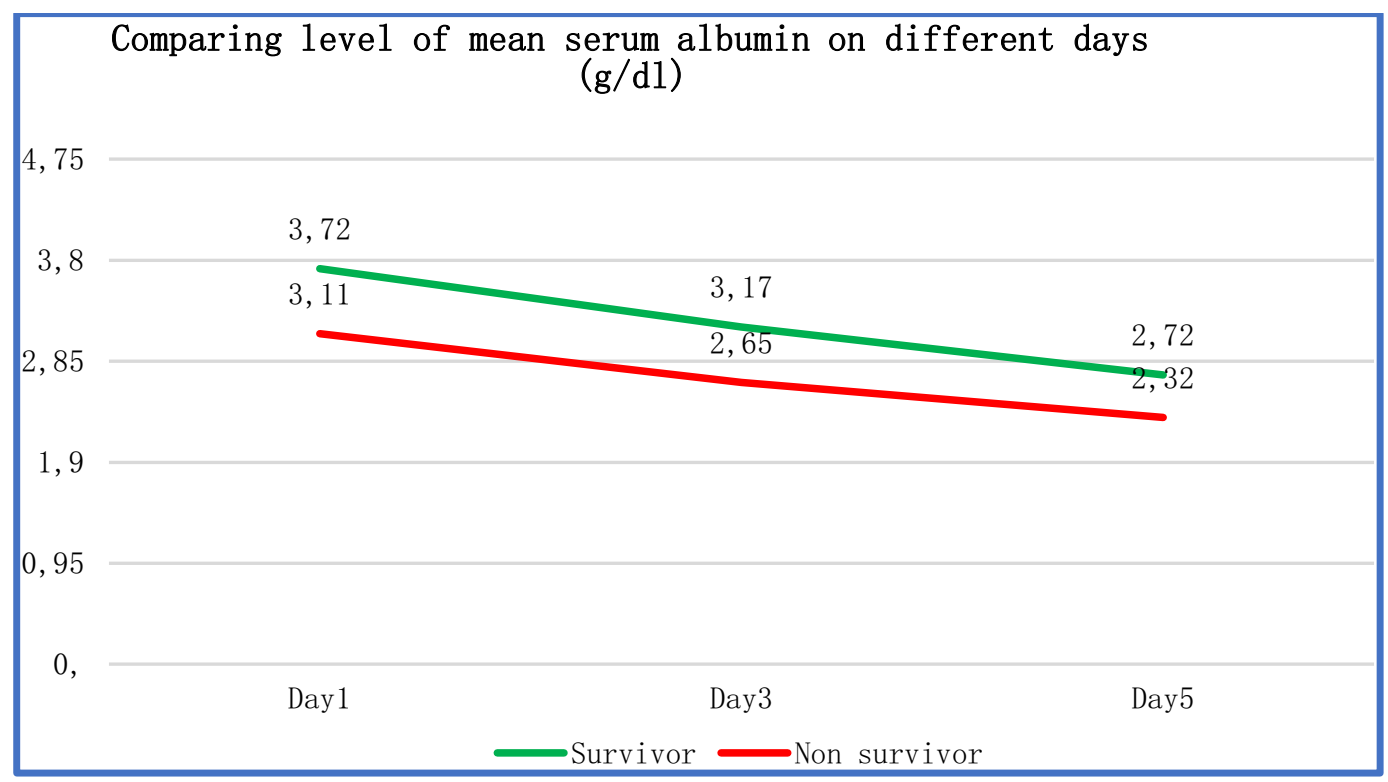

Figure 1 Comparing level of serum albumin on different days

\section{Discussion}

In this study 70 sepsis patients admitted in medical intensive care unit and surgical intensive care unit were selected. These patients were divided into Survivor and non-survivor groups.

Mean level of serum albumin at day 1 was 3.72 $\mathrm{g} / \mathrm{dl}( \pm 0.278)$ in survivor group and in nonsurvivors group, it was $3.11 \mathrm{~g} / \mathrm{dl}( \pm 0.247)$. The difference in mean serum albumin in day 1 was statistically significant with t value 9.28, df 68 and $\mathrm{p}$ value $\leq 0.001$ by unpaired t test. In a study by Nirmala et al (2015), slightly higher serum albumin was detected in Survivors versus nonsurvivors on day $1(3.46 \pm 0.25$ vs. $3.44 \pm 0.30)$, but the variance was statistically not significant $^{(10)}$. In a study by Sanket Mahajan et.al, mean serum albumin level on day of admission (Day 1) for the study group was $3.3 \mathrm{~g} / \mathrm{dl}( \pm 0.4 \mathrm{~g} / \mathrm{dl})$. In survivors, it was $3.4 \mathrm{~g} / \mathrm{dl}( \pm 0.4 \mathrm{~g} / \mathrm{dl})$ and in nonsurvivors it was $3.1 \mathrm{~g} / \mathrm{dl}( \pm 0.19 \mathrm{~g} / \mathrm{dl})$. It was significantly lower $(\mathrm{p}=0.003)$ in non-survivors. ${ }^{(11)}$ A study done by gosavi et.al also shows the mean Serum albumin on day of admission in survivors and non-survivors was $3.06 \mathrm{gm} \% \quad(+/-0.54)$ and 2.45 gm\% (+/-0.50) $(\mathrm{p}<0.01) .^{(12)}$

Mean level of serum albumin at day 3 was 3.17 $\mathrm{g} / \mathrm{dl}( \pm 0.248)$ in survivor group and in nonsurvivors group, it was $2.65 \mathrm{~g} / \mathrm{dl}( \pm 0.172)$. The 
difference in mean serum albumin in day 3 was statistically significant with t value 9.496, df 68 and $\mathrm{p}$ value $\leq 0.001$ by unpaired t test. Study by Nirmala et al. (2015) showed a fall in serum Albumin on day 3 was strongly associated with mortality among patients with Critically ill (S - 3.46 \pm $0.29 / \mathrm{NS}-2.83 \pm 0.51$ ). Mahajan et al. (2015) also reported strongest predictor of the outcome of patients is serum albumin on day 3 ( $\mathrm{S}-3.04 \pm 0.51$ / NS - $2.75 \pm 0.22)^{(10)}$.

Mean level of serum albumin at day 5 was 2.72 $\mathrm{g} / \mathrm{dl}( \pm 0.25)$ in survivor group and in nonsurvivors group, it was $2.32 \mathrm{~g} / \mathrm{dl}( \pm 0.144)$. The difference in mean serum albumin in day 5 was statistically significant with t value 7.43, df 68 and $p$ value $\leq 0.001$ by unpaired t test. In a study done by Pal. A et.al shows those who recovered to higher mean albumin value on day 5 had higher chances of survival. No mortality was seen in subjects who has serum albumin value of $>3.5 \mathrm{~g} / \mathrm{dl}$ on day 5. While Serum albumin $<2.5 \mathrm{~g} / \mathrm{dl}$ had mortality rate of $70 \%$. Thus, serum albumin value of 2.5 $\mathrm{g} / \mathrm{dl}$ on day 5 can be taken as prognostic marker of poor outcome while those who recovered to mean value of $>3.0 \mathrm{~g} / \mathrm{dl}$ have a far better prognosis in terms of mortality ${ }^{(13)}$.

In our study the decline in mean serum albumin level in survivors from day 1 to day 5 was 3.72 $\mathrm{g} / \mathrm{dl}$ to $2.72 \mathrm{~g} / \mathrm{dl}$. In non-survivors it is $3.11 \mathrm{~g} / \mathrm{dl}$ to $2.32 \mathrm{~g} / \mathrm{dl}$. This results show that both groups were gradually fall in serum albumin level but the fall in non survivors is steeper than survivors. It suggests that the rapidity with which serum albumin falls has an effect on the prognosis of the patient in terms of mortality. A decline in serum albumin indicates a poor prognosis. A study done by Mahajan et.al also shows the similar results that is a decline in serum albumin in the survivors from admission to day 10 in survivors is $0.86 \mathrm{~g} / \mathrm{dl}$. In non-survivors it is $1.09 \mathrm{~g} / \mathrm{dl}$ over a period of 10 days. $^{(11)}$

Limiatation of this study is, the role of confounding factors like baseline parameters, associated comorbidities etc. we're not accounted. Smoking and Hypertension could be independent cause of microalbuminuria. Patients with chronic kidney disease were not included in the study group.

\section{Conclusion}

In this study a serum albumin level below 3.5 $\mathrm{gm} / \mathrm{dl}$ in all three days correlates directly with poor prognosis in sepsis patient. Both survivor and non-survivor groups had gradual fall in serum albumin level from day 1, but the fall below 3.0 $\mathrm{gm} / \mathrm{dl}$ was associated with higher mortality. It suggests that the rapidity with which serum albumin falls below the normal level has an effect on the prognosis of the sepsis patient in terms of mortality. Serum albumin measurement is cheaper and it's serial measurement may help in the clinical assessment of sepsis patient's, who is at the risk of poor prognosis even in resource poor areas. Survival rate in patients with severe sepsis can be improved by early institution of intensive therapy.

\section{References}

1. Sepsis [Internet]. [cited 2020 Nov 18]. Available from:

https://www.who.int/news-room/factsheets/detail/sepsis

2. Gyawali B, Ramakrishna K, Dhamoon AS. Sepsis: The evolution in definition, pathophysiology, and management. SAGE Open Med [Internet]. 2019 Mar 21 [cited 2020 Nov 18];7. Available from: https://www.ncbi.nlm.nih.gov/pmc/articles /PMC6429642/

3. Taverna M, Marie A-L, Mira J-P, Guidet B. Specific antioxidant properties of human serum albumin. Ann Intensive Care. 2013 Feb 15;3(1):4.

4. Yin M, Si L, Qin W, Li C, Zhang J, Yang $\mathrm{H}$, et al. Predictive Value of Serum Albumin Level for the Prognosis of Severe Sepsis Without Exogenous Human Albumin Administration: A Prospective Cohort Study. J Intensive Care Med. 2018 Dec;33(12):687-94.

5. Ranzani OT, Zampieri FG, Forte DN, Azevedo LCP, Park M. C-reactive protein/albumin ratio predicts 90-day mortali- 
ty of septic patients. PloS One. 2013;8(3): e59321.

6. Nicholson JP, Wolmarans MR, Park GR. The role of albumin in critical illness. BJA Br J Anaesth. 2000 Oct 1;85(4):599-610.

7. Goldwasser P, Feldman J. Association of serum albumin and mortality risk. J Clin Epidemiol. 1997 Jun;50(6):693-703.

8. Finestone HM, Greene-Finestone LS, Wilson ES, Teasell RW. Prolonged length of stay and reduced functional improvement rate in malnourished stroke rehabilitation patients. Arch Phys Med Rehabil. 1996 Apr;77(4):340-5.

9. Spiegel DM, Breyer JA. Serum albumin: a predictor of long-term outcome in peritoneal dialysis patients. Am J Kidney Dis Off J Natl Kidney Found. 1994 Feb;23 (2):283-5.

10. Nirmala A.C., Namratha and Avinash B.H. A STUDY OF SERIAL ESTIMATIONS OF SERUM ALBUMIN AS A PROGONOSTIC MARKER. International Journal of Basic and Applied Medical Sciences ISSN: 2277-2103 (Online). :2015 Vol. 5 (1) January-April, pp. 228234/Nirmala et al.

11. Mahajan S, Agrawal A. Estimation of serial serum albumin levels as prognostic marker in critically ill patients admitted in medical ICU - a cross-sectional study. Int J Health Sci Res. 2015; 5(11):31-37.

12. Serum Albumin: A Prognostic Marker In Critically Ill Patients, IJSR - International Journal of Scientific Research(IJSR), IJSR | World Wide Journals [Internet]. [cited 2020 Nov 17]. Available from: https://www.worldwidejournals.com/intern ational-journal-of-scientific-research(IJSR)/article/serum-albumin-aprognostic-marker-in-critically-illpatients/Nzk5MA==/?is=1

13. Pal A, Jain A, Parashar MK. Serum Serial Albumin as a Prognostic Marker in Critically Ill Patients. Int J Sci Stud 2017; 5(2): 156-159. 